\title{
Nut Device
}

National Cancer Institute

\section{Source}

National Cancer Institute. Nut Device. NCI Thesaurus. Code C50084.

A threaded fastener designed to eng age a bolt. 